\title{
Study of Correlation and Path Analysis for Green Pod Yield and Its Contributing Traits in Vegetable Pea (Pisum sativum L.)
}

\author{
P.K. Kumawat ${ }^{1}$, P. Singh ${ }^{2}$, D. Singh ${ }^{3}$, S. Mukherjee ${ }^{4}$ and Mamta Kumawat ${ }^{5}$ \\ ${ }^{1}$ Agriculture Officer- Jobner, A.D. Jhotwara, Jobner, DOA, Govt. of Rajasthan, India \\ ${ }^{2}$ Horticulture, ${ }^{3} P B G$, S.K.N. College of Agriculture, (SKNAU) Jobner, Rajasthan, India \\ ${ }^{4}$ Horticulture, RARI, Durgapura (SKNAU, Jobner), Jaipur, Rajasthan, India \\ ${ }^{5}$ Bhhichawa, A.D. Kuchamancity, Nagaur, DOA, Govt. of Rajasthan, India
}

*Corresponding author

\section{A B S T R A C T}

Keywords

Pea, Green pod yield, Correlation, Path analysis

Article Info

Accepted:

25 May 2018

Available Online:

10 June 2018
Correlation at genotypic and phenotypic levels along with path coefficient analysis were studied for various yield and its component characters in twenty genotypes of pea (Pisum sativum L.) during rabi, 2009-10. Analysis of variance revealed significant difference for all the characters indicating the presence of good amount of variability in the genotypes studied. Correlation studies revealed that green pod yield per plant was positively and significantly associated with pod length, pod weight and number of grains per pod. Path coefficient analysis revealed that traits like number of pods per plant, pod weight, number of grains per pod, number of pickings and protein content were the important characters for selection of high yielding genotypes as they exerted high positive direct effect as well as positive correlation with green pod yield per plant. The result suggested that these traits could be considered as major yield contributing traits in pea.

\section{Introduction}

Pea (Pisum sativum L.) is an important crop grown throughout the world. In India, it is grown mainly as winter vegetable in the plains of North India and as summer vegetable in the hills. Pea is used as fresh vegetable, canned, processed or dehydrated and seeds are consumed as pulse. Green pods are highly nutritive, containing high percentage of digestible protein $(7.2 \%)$, carbohydrates $(19.8 \%)$ and minerals (0.8\%) (Aykroyd, 1963). Correlation coefficient is a statistical measure, which is used to find out the degree and direction of relationship between two or more variables. It measures the mutual relationship between various plant characters and determines the component characters on which selection can be exercised for genetic improvement in yield. Path coefficient analysis (Wright, 1921) is an important tool for partitioning the correlation coefficients into direct and indirect effects of independent variables on dependent variable. It has been widely used to identify traits that have significant effect on yield for potential use in 
selection. Keeping in view the study was conducted to find out correlation at genotypic and phenotypic levels and path coefficient analysis for yield and its contributing traits in pea.

\section{Materials and Methods}

The present investigation was carried out at Experimental farm, Department of Horticulture, S.K.N. College of Agriculture, Jobner, Rajasthan during rabi 2009-10. the experimental material consisted of twenty diverse pea genotypes namely, AP-1, AP-3, Arkel, VRP-5, VRP-6, VRP-7, VRP-16, VRP22, VRP-90, VRP-135, VRP-138, VRP-147, VRP-158, VRP-179, VRP-216, VRP-219, VRP-238, VRP-330, VRP-343 and EC-9126. Experiment was laid out in randomized block design with three replications. The seeds were sown at a spacing of $30 \mathrm{~cm} \times 10 \mathrm{~cm}$. Recommended agronomic practices and plant protection measures were followed to maintain optimum plant stand. The observations were recorded on five randomly selected competitive plants from each plot in every replication for the traits viz. plant height (cm), days to first flowering, days to $50 \%$ flowering, days to first fruit setting, days to first pod picking, number of pods per plant, pod length $(\mathrm{cm})$, pod weight $(\mathrm{g})$, number of grains per pod, number of pickings, pod yield per plant (g), pod yield per hectare (q), TSS of green seeds (\%) and protein content in pods $(\%)$. The data were averaged and statistically analyzed for analysis of variance as per the method suggested by Panse and sukhatme (1995). The genotypic and phenotypic correlation coefficients were calculated from the genotypic and phenotypic covariances and variances as described by Singh and Choudhary (1977) and as per formula given by Johnson et al., (1955). The estimates of direct and indirect effect were calculated by the path coefficient analysis as suggested by
Wright (1921) and elaborated by Dewey and $\mathrm{Lu}$ (1959) at both phenotypic and genotypic levels.

\section{Results and Discussion}

The analysis of variance indicated significant differences among the genotypes for all the observed characters which indicated that high amount of genetic variability was present in the genetic material.

The correlation studies revealed that in general estimates of genotypic correlation coefficients were higher than the corresponding phenotypic correlation coefficients, which indicated a strong inherent association among different traits under study (Table 2). The lower phenotypic values might be due to environmental interactions. A significant positive correlation of pod yield per plant was observed with pod weight (0.469), pod length $(0.395)$ and number of grains per pod (0.393) at phenotypic level and with number of grains per pod (0.764), pod length (0.664), pod weight (0.542) and number of pickings (0.377) at genotypic level, which, suggested that these characters could be considered as major green pod yield contributing characters in pea. Similar results were earlier obtained by Chaudhary and Sharma (2003), Sureja and Sharma (2004), Choudhary et al., (2004), Singh and Singh (2005), Nawab et al., (2008) and Guleria, Chongtham and Dua (2009).

Pod yield per plant registered significant and negative correlation with days to first flowering (-0.326) and days to first pod picking (-0.369), which, indicated that selection should be practiced for less days to flowering and first fruit setting (earliness). The results were in accordance with the findings of Chaudhary and Sharma (2003), Choudhary et al., (2004) and Sureja and Sharma (2004). 
Table.1 Phenotypic correlation coefficients (upper diagonal) and genotypic correlation coefficients (lower diagonal) between different traits in pea

\begin{tabular}{|c|c|c|c|c|c|c|c|c|c|c|c|c|c|c|c|}
\hline S. No. & Traits & PH & DFF & $50 \% \mathrm{~F}$ & DFFS & DFPP & $\mathbf{P} / \mathbf{P}$ & PL & PW & G/P & Picking & TSS & Protein & $\mathbf{Y} / \mathbf{P}$ & Y/ha \\
\hline 1 & PH & 1.000 & $0.559^{* *}$ & $0.657 * *$ & 0.631 ** & $0.712 * *$ & $0.739 * *$ & $-0.477 * *$ & $-0.649 * *$ & -0.265 & $-0.602 * *$ & $0.435^{* * *}$ & -0.136 & -0.096 & -0.039 \\
\hline 2 & DFF & 0.597 & 1.000 & $0.933^{* *}$ & $0.896^{* *}$ & $0.944 * *$ & 0.274 & -0.200 & $-0.483 * *$ & -0.0811 & $-0.699 * *$ & $0.3643^{*}$ & 0.221 & $-0.326^{*}$ & -0.251 \\
\hline 3 & $50 \% \mathrm{~F}$ & 0.694 & 0.935 & 1.000 & $0.961^{* *}$ & $0.953^{* *}$ & $0.437 * *$ & -0.299 & $-0.594 * *$ & -0.142 & $-0.614 * *$ & $0.324 *$ & 0.166 & -0.318 & -0.243 \\
\hline 4 & DFFS & 0.686 & 0.912 & 0.977 & 1.000 & $0.936^{* *}$ & $0.471 * *$ & $-0.349^{*}$ & $-0.649 * *$ & -0.220 & $-0.665^{* *}$ & $0.437 * *$ & 0.136 & $-0.369 *$ & -0.292 \\
\hline 5 & DFPP & 0.751 & 0.949 & 0.955 & 0.951 & 1.000 & $0.459^{* *}$ & -0.304 & $-0.595 * *$ & -0.116 & $-0.759^{* *}$ & $0.438 * *$ & 0.130 & -0.271 & -0.182 \\
\hline 6 & $\mathrm{P} / \mathrm{P}$ & 0.933 & 0.364 & 0.561 & 0.573 & 0.578 & 1.000 & $0.517 * *$ & $-0.785^{* *}$ & $-0.345^{*}$ & $-0.380 *$ & $0.342 *$ & -0.182 & 0.070 & 0.106 \\
\hline 7 & PL & -0.666 & -0.293 & -0.415 & -0.499 & -0.421 & -0.779 & 1.000 & $0.602 * *$ & $0.664 * *$ & 0.318 & -0.259 & $0.342 *$ & $0.395^{*}$ & $0.366 *$ \\
\hline 8 & PW & -0.828 & -0.601 & -0.739 & -0.791 & -0.734 & -0.835 & 0.966 & 1.000 & $0.488^{* *}$ & $0.475^{* *}$ & $-0.368^{*}$ & 0.177 & $0.469^{* *}$ & $0.438 * *$ \\
\hline 9 & $\mathrm{G} / \mathrm{P}$ & -0.475 & -0.140 & -0.236 & -0.351 & -0.195 & -0.527 & 0.815 & 0.776 & 1.000 & 0.225 & -0.306 & 0.182 & $0.393 *$ & 0.400* \\
\hline 10 & Picking & -0.664 & -0.735 & -0.643 & -0.693 & -0.792 & -0.421 & 0.363 & 0.587 & 0.285 & 1.000 & $-0.632 * *$ & 0.102 & 0.246 & 0.164 \\
\hline 11 & TSS & 0.583 & 0.454 & 0.397 & 0.528 & 0.543 & 0.506 & -0.325 & -0.576 & -0.419 & 0.745 & 1.000 & -0.013 & -0.151 & -0.100 \\
\hline 12 & Protein & -0.255 & 0.308 & 0.216 & 0.194 & 0.172 & -0.163 & 0.517 & 0.168 & 0.231 & 0.092 & -0.065 & 1.000 & 0.234 & 0.246 \\
\hline 13 & $\mathrm{Y} / \mathrm{P}$ & -0.211 & -0.488 & -0.440 & -0.511 & -0.378 & -0.017 & 0.664 & 0.542 & 0.764 & 0.377 & -0.271 & 0.296 & 1.000 & 0.986 ** \\
\hline 14 & Y/ha & -0.125 & -0.329 & -0.331 & -0.398 & -0.252 & 0.043 & 0.599 & 0.485 & 0.760 & 0.257 & -0.188 & 0.310 & 0.977 & 1.000 \\
\hline
\end{tabular}

$\mathrm{PH}=$ Plant height $(\mathrm{cm})$, DFF = Days taken to first flowering, 50\% F = Days to 50\% flowering, DFFS = Days to first fruit setting, DFPP = Days to first pod picking, $\mathrm{P} / \mathrm{P}=$ Number of pods/plant, $\mathrm{PL}=$ Pod length $(\mathrm{cm}), \mathrm{PW}=$ Pod weight $(\mathrm{g}), \mathrm{G} / \mathrm{P}=$ Number of grains/pod, Pickings $=\mathrm{Number}$ of pickings, Y/P = Yield/plant $(\mathrm{g}), \mathrm{Y} / \mathrm{ha}=$ Yield/hectare $(\mathrm{q}), \mathrm{TSS}=\mathrm{T}$. S.S. of green seeds $(\%)$, Protein $=$ Protein content in pods $(\%)$.

** Significant at $\mathrm{P}=0.01$ level of significance

* Significant at $\mathrm{P}=0.05$ level of significance 
Table.2 Direct (diagonal) and indirect effects of different characters on pod yield per plant in pea at genotypic and phenotypic level

\begin{tabular}{|c|c|c|c|c|c|c|c|c|c|c|c|c|c|c|}
\hline Characters & & PH & DFF & $\mathbf{5 0 \%} \mathbf{F}$ & I-FS & I-PP & $\mathbf{P} / \mathbf{P}$ & PL & PW & G/P & Pickings & TSS & Protein & correlation with $\mathrm{Y} / \mathrm{P}$ \\
\hline \multirow[t]{2}{*}{ PH } & $\mathbf{P}$ & 0.4528 & -0.5318 & 0.0209 & -0.1673 & 0.5764 & -0.0355 & -0.1261 & -0.2356 & -0.0149 & 0.0086 & -0.0087 & -0.0351 & -0.0964 \\
\hline & G & -0.4653 & -0.7433 & 0.0790 & -0.5402 & 1.5880 & 1.1873 & 0.1924 & -1.2532 & -0.0543 & -0.0601 & -0.0417 & -0.0993 & -0.2108 \\
\hline \multirow[t]{2}{*}{ DFF } & $\mathbf{P}$ & 0.2535 & -0.9500 & 0.0297 & -0.2377 & 0.7644 & -0.0132 & -0.0528 & -0.1752 & -0.0046 & 0.0099 & -0.0073 & 0.0571 & $-0.3261 *$ \\
\hline & G & -0.2779 & -1.2447 & 0.1063 & -0.7184 & 2.0045 & 0.4630 & 0.0847 & -0.9102 & -0.0160 & -0.0666 & -0.0325 & 0.1196 & $-0.4882 * *$ \\
\hline \multirow[t]{2}{*}{$50 \% \mathrm{~F}$} & $\mathbf{P}$ & 0.2975 & -0.8859 & 0.0318 & -0.2548 & 0.7721 & -0.0210 & -0.0789 & -0.2157 & -0.0080 & 0.0087 & -0.0065 & 0.0429 & -0.3179 \\
\hline & G & -0.3232 & -1.1636 & 0.1137 & -0.7698 & 2.0182 & 0.7137 & 0.1200 & -1.1196 & -0.0270 & -0.0582 & -0.0284 & 0.0840 & $-0.4402 * *$ \\
\hline \multirow[t]{2}{*}{ I-FS } & $\mathbf{P}$ & 0.2857 & -0.8513 & 0.0306 & -0.2652 & 0.7578 & -0.0226 & -0.0921 & -0.2357 & -0.0124 & 0.0095 & -0.0088 & 0.0352 & $-0.3694 *$ \\
\hline & G & -0.3192 & -1.1353 & 0.1111 & -0.7876 & 2.0094 & 0.7285 & 0.1444 & -1.1976 & -0.0400 & -0.0627 & -0.0378 & 0.0755 & $-0.5113 * *$ \\
\hline \multirow[t]{2}{*}{ I-PP } & $\mathbf{P}$ & 0.3223 & -0.8966 & 0.0303 & -0.2482 & 0.8099 & -0.0221 & -0.0802 & -0.2161 & -0.0065 & 0.0108 & -0.0088 & 0.0336 & -0.2715 \\
\hline & G & -0.3497 & -1.1807 & 0.1086 & -0.7489 & 2.1131 & 0.7355 & 0.1218 & -1.1119 & -0.0222 & -0.0717 & -0.0389 & 0.0668 & $-0.3783 *$ \\
\hline \multirow[t]{2}{*}{$\mathbf{P} / \mathbf{P}$} & $\mathbf{P}$ & 0.3347 & -0.2608 & 0.0139 & -0.1249 & 0.3721 & -0.0481 & 0.1365 & -0.2851 & -0.0194 & 0.0054 & -0.0069 & -0.0469 & 0.0705 \\
\hline & G & -0.4343 & -0.4531 & 0.0638 & -0.4510 & 1.2218 & 1.2720 & 0.2251 & -1.2638 & -0.0601 & -0.0381 & -0.0362 & -0.0635 & -0.0175 \\
\hline \multirow[t]{2}{*}{ PL } & $\mathbf{P}$ & -0.2162 & 0.1900 & -0.0095 & 0.0925 & -0.2460 & -0.0248 & 0.2641 & 0.2187 & 0.0375 & -0.0045 & 0.0052 & 0.0884 & 0.3952* \\
\hline & G & 0.3099 & 0.3649 & -0.0472 & 0.3936 & -0.8907 & -0.9910 & -0.2889 & 1.4627 & 0.0931 & 0.0329 & 0.0233 & 0.2010 & $0.6636^{* *}$ \\
\hline \multirow[t]{2}{*}{ PW } & $\mathbf{P}$ & -0.2939 & 0.4584 & -0.0189 & 0.1722 & -0.4821 & 0.0377 & 0.1591 & 0.3630 & 0.0275 & -0.0068 & 0.0074 & 0.0461 & $0.4699 * *$ \\
\hline & G & 0.3852 & 0.7483 & -0.0841 & 0.6230 & -1.5519 & -1.0617 & -0.2791 & 1.5140 & 0.0886 & 0.0532 & 0.0412 & 0.0653 & $0.5420 * *$ \\
\hline \multirow[t]{2}{*}{ G/P } & $\mathbf{P}$ & -0.1199 & 0.0770 & -0.0045 & 0.0584 & -0.0939 & 0.0166 & 0.1755 & 0.1772 & 0.0564 & -0.0032 & 0.0061 & 0.0469 & $0.3926^{*}$ \\
\hline & G & 0.2215 & 0.1746 & -0.0269 & 0.2764 & -0.4112 & -0.6699 & -0.2356 & 1.1750 & 0.1141 & 0.0258 & 0.0300 & 0.0899 & $0.7637 * *$ \\
\hline \multirow[t]{2}{*}{ Pickings } & $\mathbf{P}$ & -0.2726 & 0.6643 & -0.0195 & 0.1763 & -0.6146 & 0.0183 & 0.0839 & 0.1727 & 0.0127 & -0.0142 & 0.0127 & 0.0264 & 0.2464 \\
\hline & G & 0.3091 & 0.9152 & -0.0731 & 0.5455 & -1.6740 & -0.5359 & -0.1049 & 0.8895 & 0.0325 & 0.0905 & -0.0534 & 0.0358 & $0.3769 *$ \\
\hline \multirow[t]{2}{*}{ TSS } & $\mathbf{P}$ & 0.1968 & -0.3461 & 0.0103 & -0.1158 & 0.3544 & -0.0166 & -0.0685 & -0.1338 & -0.0172 & 0.0090 & -0.0201 & -0.0035 & -0.1510 \\
\hline & G & -0.2712 & -0.5656 & 0.0452 & -0.4159 & 1.1476 & 0.6437 & 0.0940 & -0.8721 & -0.0478 & 0.0675 & -0.0716 & -0.0254 & -0.2715 \\
\hline \multirow[t]{2}{*}{ Protein } & $\mathbf{P}$ & -0.0615 & -0.2100 & 0.0053 & -0.0362 & 0.1054 & 0.0087 & 0.0903 & 0.0648 & 0.0102 & -0.0015 & 0.0003 & 0.2583 & 0.2342 \\
\hline & G & 0.1188 & -0.3829 & 0.0246 & -0.1530 & 0.3630 & -0.2077 & -0.1494 & 0.2545 & 0.0264 & 0.0083 & 0.0047 & 0.3887 & 0.2961 \\
\hline
\end{tabular}

$\mathrm{PH}=$ Average plant height $(\mathrm{cm}), \mathrm{DFF}=$ Days taken to first flowering, $50 \% \mathrm{~F}=$ Days to $50 \%$ flowering, $\mathrm{I}-\mathrm{FS}=$ Days to first fruit setting, I-PP $=\mathrm{Days}$ to first pod picking, $\mathrm{P} / \mathrm{P}=$ Average number of pods per plant, $\mathrm{PL}=$ Average pods length $(\mathrm{cm}), \mathrm{PW}=$ Average pod weight $(\mathrm{g}), \mathrm{G} / \mathrm{P}=$ Average number of grains per pod, Pickings $=$ Average number of pickings, $\mathrm{Y} / \mathrm{P}=$ Average yield per plant $(\mathrm{g}), \mathrm{Y} / \mathrm{ha}=$ Average yield per hectare $(\mathrm{q})$, TSS $=$ T.S.S. of green seeds $\left({ }^{0} \mathrm{~B}\right)$, Protein $=$ Protein content in pods $(\%)$

*** significant at $\mathrm{P}=0.01$ level of significance

* significant at $\mathrm{P}=0.05$ level of significance

Residual effects: phenotypic $=0.511$, genotypic $=-0.358$

(Note: Diagonal values are direct effect.) 
Therefore, it can be concluded that, during selection of high yielding genotypes in pea major emphasis should be given on pod weight, pod length, number of grains per pod, days to first fruit setting and days to first flowering as these are significantly associated with pod yield hense, these characters could be considered reliable indices for selection, to enhance the pod yield.

Path coefficient analysis revealed that, days taken to first pod picking exhibited maximum positive direct effect on green pod yield per plant (2.1131) at genotypic level followed by average pod weight (1.5140), number of pods per plant (1.2720), protein content (0.3887), average number of grains per pod $(0.1141)$, days taken to 50 per cent flowering (0.1137) and average number of pickings (0.0905). The present findings was in close proximately to the earlier work done by Natarajan and Arumugam (1980); Singh et al., (1992); and Usmani and Dubey (2007). The highest negative direct effect was exerted by days taken to first flowering, followed by days to first fruit setting, plant height, average pod length and TSS of green seeds. These results were in partial agreement with those of Sureja and Sharma (2004) for appearance of first flower, by Sharma et al., (2007) for TSS and by Sardana et al., (2007) for plant height.

Days to 50 per cent flowering exhibited maximum positive indirect effect on pod yield per plant via days to first pod picking, number of pods per plant, pod length and protein content at genotypic level. Days to first pod picking had positive indirect effect through number of pods per plant, pod length, days to 50 per cent flowering and protein content. Average number of pods per plant had positive indirect effect on pod yield through days to first pod picking, pod length and days to 50 per cent flowering. Average pod weight exhibited positive indirect effect via days to first flowering, days to first fruit setting, plant height, number of grains per pod, protein content, number of pickings and TSS of green seeds.

Average number of pickings had positive indirect effect on pod yield through days to first flowering, average pod weight, days to first fruit setting, plant height, protein content and number of grains per pod. Whereas, protein content exerted positive indirect effect via day to first pod picking average pod weight, plant height, number of grains per pod, days to 50 per cent flowering, number of pickings and TSS of green seeds. The residual effect at phenotypic (0.511) and genotypic (0.358 ) levels was very low which indicated that the green pod yield per plant was ultimately the result of the traits under study having adequate variability.

Keeping in view the estimates of correlation coefficient and direct and indirect contribution of component traits toward pod yield per plant, indirect selection practices on the basis of days taken to first pod picking, average pod weight, number of pods per plant, protein content, number of grains per pod, days to 50 per cent flowering and number of pickings would be rewarding in the genotypes under study enhancing the pod yield per plant as well as per hectare.

\section{References}

Aykroyd, WR. 1963. ICMR Special Republic Series. No. 42.

Burton, GW. 1952. Quantitative inheritance in grasses. Proc. $6^{\text {th }}$ International Grassland congress. pp. 277-283.

Burton, GW and De Vane, EM. 1953. Estimating heritability in tall fescue (Festuca arundinacea) from replicated clonal material. Agronomy Journal 45: 478-487.

Chaudhary, DK and Sharma, RR. 2003. Genetic variability, correlation and 
path analysis for green pod yield and its component in garden pea. Indian Journal of Horticulture 60 (3): 251256.

Choudhary, DK, Sharma, RR and Sureja, AK. 2004. Correlation and path analysis studies across the generations in garden pea. Indian Journal of Horticulture 61(2): 163-167.

Guleria, Sonali, Chongtham, Nirmala and Dua, Saroj (2009). Correlation and path in pea. Crop Research (Hisar) 38 (1): 179-183.

Gupta, AJ, Singh, YU and Verma, TS. 2006. Genetic variability and heritability in garden pea (Pisum sativum L.). Indian Journal of Horticulture 63 (3): 332334.

Hanson, C.H, Robinson, HF and Comstock, RE. 1956. Biometrical studies on yield in segregating population of Korean Lespedeza. Agronomy Journal, 48: 262-272.

Johnson, HW, Robinson, HF and Comstock, RE. 1955. Estimates of genetic and environmental variability in soybeans. Agronomy Journal 47: 314-318.

Kaur, H, Singh, M and Brar, PS. 2007. Genetic variability in pea (Pisum sativum L.). Journal of Research, Punjab Agriculture University 44 (4): 301-303.

Nawab, NN, Subhani, GM, Mahmood, K, Shakil, Q and Saeed, A. 2008. Genetic variability correlation and path analysis studies in garden pea (Pisum sativum L.). Journal of Agricultural Research (Pakistan) 46 (4): 333-340.

Panse, VG and Sukhatme, PV. 1995. Statistical Methods for Agricultural Workers. ICAR, New Delhi.

Sardana, S, Mahajan, RK, Gautam, NK and Ram, B. 2007. Genetic variability in pea (Pisum sativum L.) germplasm for utilization. SABRAO Journal of Breeding and Genetics 39 (1): 31-41.

Sharma, A, Sood, M, Rana, A and Singh, Y. 2007. Genetic variability and association studies for green pod yield and component horticultural traits in garden pea under high hill dry temperate conditions. Indian Journal of Horticulture 64 (4): 410-414.

Singh, J D and Singh, I P. (2005). Studies on correlation and path coefficient analysis in field pea (Pisum sativum L.). National Journal of Plant Improvement. 7 (1): 59-60.

Singh, RK and Choudhary, BD. 1977. Variance and Covariance analysis. Biometrical methods in quantitative genetic analysis. Kalyani Publisher, Ludhiana (Rev. Ed., 1985). pp: 39-68.

Sureja, AK and Sharma, RR. 2000. Genetic variability and heritability studies in garden pea (Pisum sativum L.). Indian Journal of Horticulture 57 (3): 243 247.

Sureja, AK and Sharma, RR. 2004. Path analysis for yield and its attributes in garden pea (Pisum sativum L. sub sp. hortense Asch and Graebn). Indian Journal of Horticulture 61 (1): 42-45.

\section{How to cite this article:}

Kumawat, P.K., P. Singh, D. Singh, S. Mukherjee and Mamta Kumawat. 2018. Study of Correlation and Path Analysis for Green Pod Yield and Its Contributing Traits in Vegetable Pea (Pisum sativum L.). Int.J.Curr.Microbiol.App.Sci. 7(06): 3497-3502. doi: https://doi.org/10.20546/ijcmas.2018.706.409 